\title{
Smulkiujjų skaidulų neuropatija: klinikinė charakteristika, diagnostikos metodai, ligos priežastys ir gydymas
}

\section{E. Paulèkas \\ D. Garšvienė \\ K. Petrikonis}

Lietuvos sveikatos mokslu universitetas, Medicinos akademija, Neurologijos klinika

\begin{abstract}
Santrauka. Smulkiujų skaidulų neuropatija (SSN) yra plonai mielinizuotų A $\delta$ ir nemielinizuotų C nervinių skaidulų liga, kuri dažniausiai kliniškai pasireiškia simetriniais, nuo ilgio priklausančiais neuropatinio ir autonominio pobūdžio simptomais. Retesniais atvejais būdingi asimetriniai, nuo ilgio nepriklausantys židininiai ar daugiažidininiai klinikiniai požymiai. Izoliuotos SSN diagnostika vis dar išlieka sudètinga, kadangi dažniausiai standartiniame elektroneuromiografiniame tyrime patologiniai nervų laidumo radiniai neaptinkami, o interpretuojant pacientų nusiskundimus iškyla sunkumų. Ją palengvina kiekybinis intraepiderminių nervinių skaidulų tankio matavimas odos biopsinèje medžiagoje ir kiekybinis jutimo ar autonominių simptomų įvertinimas. SSN priežasčių spektras yra gana platus. Nustatyta, kad metaboliniai, imuniniai, neurotoksiniai ir kiti veiksniai gali lemti ligos išsivystymą, tačiau visgi apie $50 \%$ visų SSN atvejų priežastys išlieka neaiškios. Literatūros duomenimis, iki trečdalio idiopatinès SSN pacientų ligos etiologija gali būti genetinės kilmės - nustatytas SSN ryšys su natrio jonų kanalų mutacijomis - $\mathrm{Na}_{\mathrm{v}} 1.7$ ir $\mathrm{Na}_{\mathrm{v}} 1.8$ (atitinkamai koduojami SCN9A ir SCN10A genų). Klinikineje praktikoje svarbu ieškoti galimų SSN priežasčių ir, jas nustačius, skirti ne tik simptominius, bet ir etiopatogenetinius gydymo būdus. Šioje literatūros apžvalgoje aptarsime pagrindinius SSN klinikinius požymius, ligos priežastis, galimus diagnostinius metodus ir gydymą.
\end{abstract}

Raktažodžiai: smulkiųjų skaidulų neuropatija, skausminga neuropatija, odos biopsija, intraepiderminès nervinės skaidulos, kiekybinis jutimo įvertinimas, kiekybinis sudomotorinio reflekso vertinimas, ragenos konfokalinè mikroskopija.

\section{IVADAS}

Smulkiụjų skaidulų neuropatija (SSN) priskiriama neuropatijų grupei, kurią apibūdina selektyvus arba dominuojantis periferinių mažo diametro plonai mielinizuotų $\mathrm{A} \delta$ ir nemielinizuotų $C$ nervinių skaidulų pažeidimas [1]. Dèl šių abiejų skaidulų tipų pažeidimo atsiranda ne tik skausmas ir temperatūros jutimo sutrikimas, bet ir autonominès nervų sistemos pažeidimai, kurie yra siejami su C nervinèmis skaidulomis [2].

\footnotetext{
Adresas:

Erlandas Paulekas

Lietuvos sveikatos mokslu universitetas,

Medicinos akademija, Neurologijos klinika

Eiveniu g. 2, LT-50009 Kaunas

El.paštas erlandas.paulekas@gmail.com
}

Nesant tikslaus apibrèžimo ir aiškių diagnostikos kriterijų, buvo manoma, kad SSN yra reta ligų grupè, tačiau, epidemiologinių tyrimų duomenimis, ligos paplitimas nėra mažas. Pavyzdžiui, epidemiologinio tyrimo Olandijoje, atlikto 2006-2011 m., metu buvo nustatyta, kad šios ligos dažnis 12 atvejų 100000 gyventojų per metus, o paplitimas - 53 atvejai 100000 gyventojuc per metus [3]. SSN diagnostika vystėsi pastaruosius du dešimtmečius, kartu su odos biopsijos prieinamumu ir standartizavimu. Esant tik smulkiuju skaidulų pažaidai, dèl plono mielino sluoksnio arba jo nebuvimo standartinė elektroneuromiografija (ENMG), tirianti stambiưjų nervinių skaidulų ( $A \alpha$ ir $A \beta)$ funkciją, nèra tokia vertinga, nebent SSN diagnostikai taikomi papildomi neurofiziologiniai tyrimai - odos tylusis periodas (OTP) ir skausminio fleksinio reflekso (RIII atsako) tyrimas [4].

Manoma, kad didejjantis ligų, galinčių sukelti SSN, paplitimas ir gerejjančios diagnostikos galimybės lems, kad

(C) Neurologijos seminarai, 2020. Open Access. This article is distributed under the terms of the Creative Commons Attribution 4.0 International License CC-BY 4.0 (http://creativecommons.org/licenses/by/4.0/), which permits unrestricted use, distribution, and reproduction in any medium, provided you give appropriate credit to the original author(s) and the source, provide a link to the Creative Commons license, and indicate if changes were made. 
1 lentelè. Smulkiụų nervinių skaidulų tipai ir jų charakteristikos. Adaptuota pagal Damien Sène [6]

\begin{tabular}{|c|c|c|c|l||}
\hline Nervinių skaidulų tipas & Mielinas & Skersmuo $(\mu \mathbf{m})$ & Impulso plitimo greitis $(\mathbf{m} / \mathbf{s})$ & Funkcija \\
\hline A $\delta$ & Mielinizuotos & $1-5$ & $5-40$ & Greito skausmo, šalčio \\
\hline C & Nemielinizuotos & $0,3-1,5$ & $0,5-2$ & Lèto skausmo, karščio, autonominės \\
\hline
\end{tabular}

klinikinejje praktikoje su šia patologija susidursime vis dažniau [5].

\section{APIBRĖŽIMAS IR KLINIKINE் CHARAKTERISTIKA}

Periferinejje nervų sistemoje skiriamos siauro / mažo diametro plonai mielinizuotos A $\delta$ skaidulos ir nemielinizuotos $\mathrm{C}$ nervinès skaidulos. Somatosensorinès $\mathrm{A} \delta$ ir $\mathrm{C}$ skaidulos inervuoja odą, pasibaigdamos epidermyje. A $\delta$ yra jautrios šalčiui ir greitam ar staigiam skausmui, o polimodalinès C tipo skaidulos - šilumai, taip pat lètam, ilgesnès trukmės skausmui $[6,7]$. Be to, smulkiosios skaidulos atlieka svarbų vaidmenį autonominėje nervų sistemoje, nes plonai mielinizuotos skaidulos yra preganglinès, o nemielinizuotos C skaidulos - postganglinès, taip inervuojamos prakaito liaukos, kraujagyslès, širdis ir kt. (1 lentelè) [8].

Dauguma ligų, sukeliančių smulkiưjų skaidulų neuropatiją, tipiškai sukelia nuo ilgio priklausantị smulkiųjų skaidulų pažeidimą - „kojinių“ ir „pirštinių“ tipo jutimų sutrikimą galūnėse [9]. Smulkiųų A $\delta$ ir C nervinių skaidulų pažaidą lydi spontaniškas, atkaklus, varginantis skausmas, lokalizuotas distalinėse galūnių dalyse, apibūdinamas kaip deginantis ar duriantis ir trunkantis dažniausiai ilgiau kaip 6 mèn. [7]. Skausmo pojūti lydi niežejjimas, badymas lyg adatèlèmis, dilgčiojimas (parestezija, dizestezija). Taip pat tokie pacientai netoleruoja patalynès lietimosi, kojinių dèvèjimo ar kito išorinio dirgiklio (alodinija, hiperalgezija) [10]. Ligai progresuojant ir sunykus smulkio-

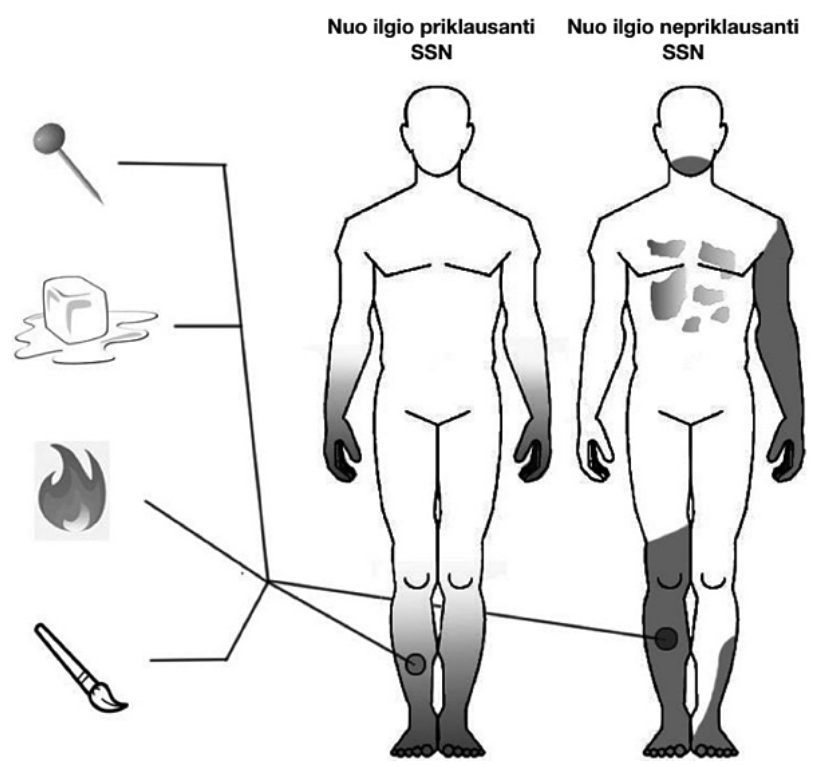

1 pav. Smulkiujų skaidulų neuropatijos klinikinès išraiškos. Adaptuota pagal Astrid J Terkelsen, Pall Karlsson [4] sioms skaiduloms, „teigiamus" sensorinius simptomus keičia „neigiami“", kurie yra susiję su specifinių jutimų sumažèjimu (hipoestezija, hipoalgezija) [7]. Svarbu įvertinti, kad tokiems pacientams neurologinio ištyrimo metu nerasime raumenų jėgos, sausgyslès / antkaulio refleksų, giliųjų ir vibracinio jutimų sutrikimų, koordinacijos pokyčių ar nervų laidumo sutrikimų standartinio ENMG tyrimo metu, priešingai, nei esant stambiųjų skaidulų (A $\alpha$ ar $A \beta)$ neuropatijai, kuri sukelia subjektyvius ir objektyvius periferinių nervų pažeidimo požymius bei pokyčius neurofiziologinių tyrimų metu (1 pav.) [7, 8].

Retesniais atvejais SSN sukelia asimetrini, nuo ilgio nepriklausantị pažeidimą - židininę ar daugiažidininę mononeuropatiją ar ganglionopatiją (vystosi selektyvi nugarinio mazgo juntamųų neuronų smulkiujų skaidulų pažaida), kuri dažniausiai yra autoimuninès, idiopatinès kilmès arba išsivysčiusi, sergant Sjogreno sindromu [11, 12]. Esant tokiai mononeuropatijai ar ganglionopatijai, simptomai pasireiškia skausmu ar somatinių jutimų sutrikimu daugelyje kūno vietų: veide, liežuvyje, skalpo ar liemens srityje, vienoje galūnèje [13]. Dèl šios neịprastos klinikinių simptomų lokalizacijos yra sunku diagnozuoti šį ligos potipi. Pastebèta sąsaja, kad, esant difuzinio skausmo sindromui, fibromialgijai ir Ehlers Danlos sindromui, nustatomas toks, nuo ilgio nepriklausantis smulkiujų skaidulų, pažeidimas (1 pav.) [14, 15].

Be somatosensorinių simptomų, svarbu įvertinti ir subtilius autonominės nervų sistemos pokyčius esant SSN, nulemiančius ligos kompleksiškumą ir heterogeniškumą [16]. Autonominès nervų sistemos sutrikimai gali pasireikšti sumažèjusiu ar padidejjusiu prakaitavimu, odos spalvos pasikeitimu, sausumu, atrofija. Gali pasireikšti ir kitų sistemų pažeidimu - ortostatine hipotenzija, virškinimo, šlapinimosi ar lytinès sistemos disfunkcija [8].

\section{DIAGNOSTINIAI TYRIMAI}

Anksčiau aprašyti dažniausiai pasireiškiantys nusiskundimai ir neurologiniai simptomai klinikinèje praktikoje padeda įtarti SSN, tačiau svarbu atmesti kitas galimas šių simptomų priežastis. Šioje dalyje aptarsime diferencinei diagnostikai atliekamus subjektyvius ir objektyvius tyrimus bei galimas papildomas tyrimo priemones ar jų alternatyvas.

Diferencinei diagnostikai atliekamas standartinis ENMG tyrimas, kuriuo dažniausiai siekiama atmesti galimą stambiųu ų skaidulų pažaidą. ENMG atspindi storai mielinizuotų skaidulų funkciją ir negali nustatyti smulkiųjų nervinių skaidulų funkcijos, kurių diametras - mažesnis nei 7-10 $\mu \mathrm{m}$ [8], jei netaikomi svarbūs, papildomi neurofi- 


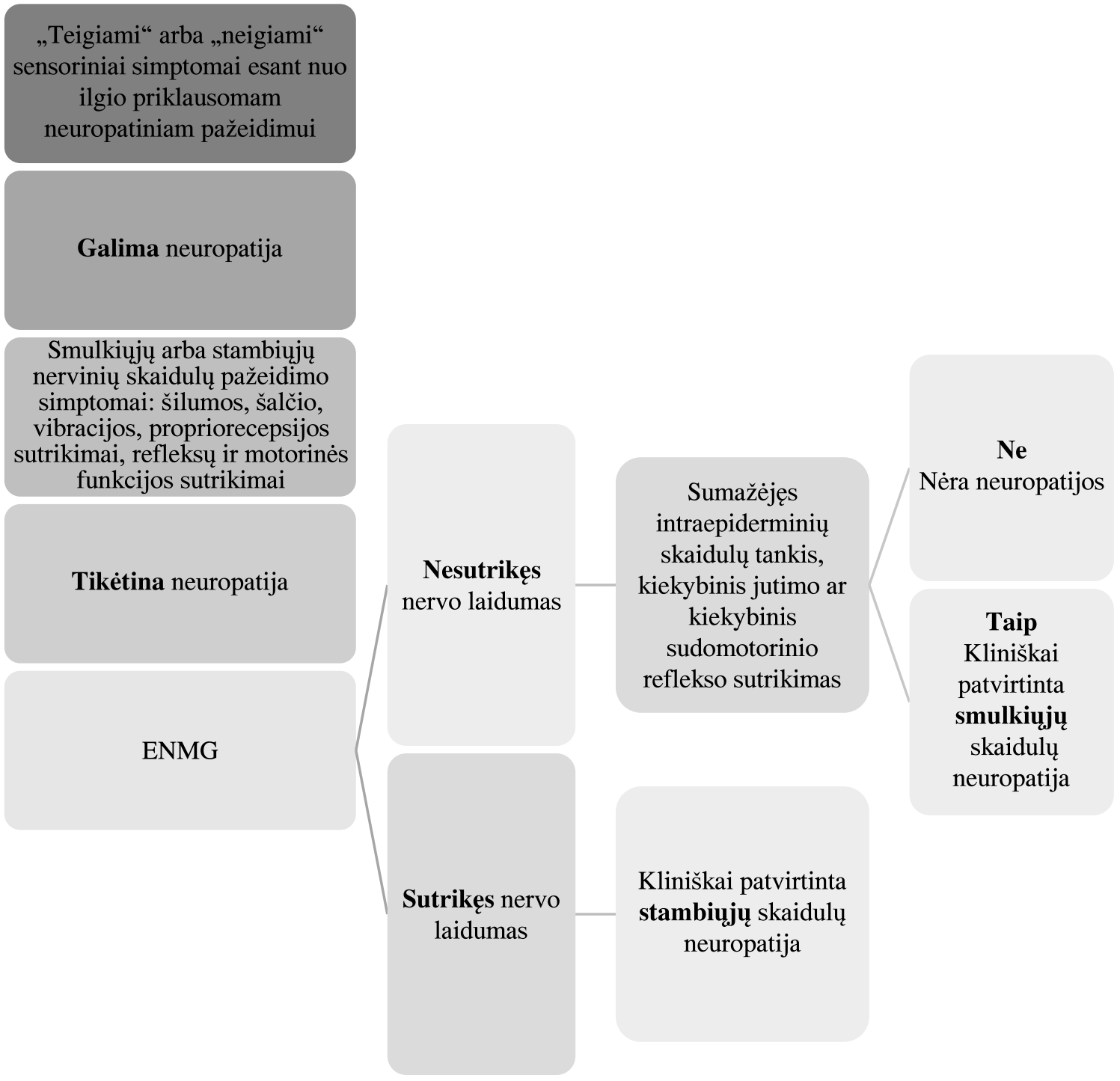

2 pav. Smulkiujų skaidulų neuropatijos diagnostikos algoritmas.

ziologiniai tyrimai - daug vilčių atnešęs odos tylusis periodas (OTP), aprašytas Hoffman, skausminio fleksinio reflekso (RIII atsako) tyrimas ir lazerio sukeltieji potencialai $[8,17]$.

OTP - tai slopinamojo spinalinio reflekso sukeltas trumpalaikis elektromiografinio aktyvumo išnykimas valingo raumens susitraukimo metu, stimuliuojant periferini juntamaji nervą skausminga elektros srove [18]. Šiuo metu yra sukaupta išties daug tyrimų ir ịrodymų, kad OTP objektyviai ir jautriai atspindi plonuju $\mathrm{A} \delta$ nervinių skaidulų funkciją ìvairių periferinių juntamųjų neuropatijų metu [18-23].

Skausminio fleksinio reflekso (RIII atsako) tyrimas yra dar vienas svarbus metodas smulkiųjų skausminių skaidulų funkcijai įvertinti. Nustatyta, kad reflekso slenkstis ypač gerai koreliuoja su subjektyviu skausmo slenksčiu [24, 25]. Tačiau, vertinant RIII refleksą, derètų nepamiršti svarbių skausmo slenksčiui ịtaką darančių faktorių: slenksčio kitimo per parą, įvairių miego fazių metu, širdies ciklo metu, kas susiję su karotidinių baroreceptorių akty- vumu ir skausmo moduliavimu, slenksčio priklausomybès nuo amžiaus, lyties ir svorio [26-28].

Lazerio sukelti potencialai (LSP) ịvertina A $\delta$ ir galbūt $\mathrm{C}$ nervines skaidulas periferijoje bei nugarinị gumburo laidą (lot. tr. spinothalamicus). Gauti atsakai ị lazerio stimuliaciją yra kiekybiniai ir specifiniai smulkiosioms skaiduloms bei nugariniam gumburo laidui (lot. tr. spinothalamicus). LSP jautrumas siekia 70-80 \%, diagnozuojant SSN [6]. Šio metodo taikymas Lietuvoje yra apribotas dèl riboto lazerio irrenginių prieinamumo.

Kiekybinis jutimo įvertinimas yra neinvazyvus tyrimo metodas, paremtas subjektyviu somatosensorinès nervų sistemos funkcijos vertinimu [29]. Tam naudojami įvairūs mechaniniai, temperatūros, vibraciniai, nocicepciniai ir ne nocicepciniai stimulai bei vertinamas jutimo ir skausmo slenkstis bei stimulo ir atsako funkcijos [30]. Pavyzdžiui, Vokietijos neuropatinio skausmo tyrimo draugija savo diagnostikos protokole turi 7 testus, kuriais vertinama 13 jutiminès funkcijos parametrų [31]. Tyrimas pasižymi ilga atlikimo trukme ir subjektyviu simptomų vertinimu, 
todèl jam atlikti reikalingas adekvatus, neturintis pažinimo funkcijų sutrikimo pacientas ir apmokyti tyrèjai [29]. Galbūt dèl to jis nèra taip plačiai paplitęs klinikinejje praktikoje [8]. Šis tyrimas taip pat nèra pakankamai jautrus diferencijuojant periferinès ir centrinès kilmès pažeidimą, todèl, diagnozuojant galimą smulkiųų skaidulų neuropatiją, yra daugiau kaip papildoma priemonė [4].

Per pastaruosius dešimtmečius odos biopsija ir kiekybinis intraepiderminių nervinių skaidulų tankio (IST) matavimas tapo svarbiausiu, validizuotu tyrimu SSN diagnostikoje [5, 32]. Periferinio nervo biopsija dabar atliekama rečiau, tik esant neaiškiems atvejams, kai neinvazyvūs tyrimo metodai yra neinformatyvūs, ịtariant vaskulitą, uždegimines polineuropatijas ar amiloidozę [33].

Odos prakalo biopsijos metu imama $3 \mathrm{~mm}$ odos ir poodžio biopsija iš distalinès kojos dalies, dažniausiai $10 \mathrm{~cm}$ virš šoninės kulkšnies (lot. malleolus lateralis), tačiau gali būti imama iš bet kurios vietos, ypač ịtariant nuo ilgio nepriklausanti pažeidimą $[34,35]$. Ši procedūra gerai toleruojama ir turi mažą komplikacijų dažni [36]. Odos ir poodžio bioptatas yra dažomas PGP 9.5 antigenu ir tiriamas šviesaus lauko imunohistocheminiu arba imunofluorescenciniu būdu [37, 38]. Abiems būdams yra prieinamos validizuotos norminès vertès, priklausančios nuo tiriamojo amžiaus ir lyties, tačiau nèra validizuota metodika, taikant blisterio poodžio bioptato paėmimą, nors jam atlikti nereikalinga vietinė nejautra ir yra minimali kraujavimo rizika [35].

Esant smulkiujų nervinių skaidulų pažeidimui, stebimas sumažėjęs IST, nervo paburkimas ar nervo išsišakojimo pokyčiai. Nemielinizuotos skaidulos lokalizuojasi epidermyje / dermoje kaip A $\delta$ ar C skaidulos. Sumažèjęs intraepiderminių nervinių skaidulų tankis koreliuoja su neuropatijos simptomais. Šio tyrimo jautrumas siekia $90 \%$, o specifiškumas - apie $95 \%$ [8]. Taip pat, atliekant odos biopsijos tyrimą, galima įvertinti prakaito liaukų inervaciją, Langerhanso ląsteles, kurių kiekio padidejjimas sietinas su skausminga SSN ar skausminga diabetine neuropatija, palyginus su sveikais tiriamaisiais [39]. Tačiau šių ląstelių vertinimas nėra įtrauktas į SSN diagnostikos protokolą.

Kiekybinis sudomotorinio reflekso - prakaito gamybos - vertinimas gali būti įvertintas neinvazyviais metodais, vertinant postganglinę simpatinę nemielinizuotų arba plonai mielinizuotuc cholinerginių skaidulų, kurios inervuoja prakaito liaukas, funkciją. Tam naudojamas $10 \%$ acetilcholinas, kuris įvedamas ị odą nedidele elektros srove. Taip yra stimuliuojamos nemielinizuotos $\mathrm{C}$ skaidulos, o prakaitavimas vertinamas sudorometru [40]. Šiam tyrimui atlikti reikalingas specialus inventorius, tyrimo atlikimas yra techniškai sudètingas ir užimantis daug laiko. Diagnozuojant SSN, šio tyrimo jautrumas siekia apie 50 \% [41].

Autonominės nervų sistemos disfunkcijai nustatyti taip pat gali būti naudojamas simpatinių odos atsakų tyrimas. Tai nesudėtingas smulkiųjų skaidulų sudomotorinès funkcijos tyrimas, kuris gali papildyti rutininę ENMG. Nustatyta, kad simpatinių odos atsakų tyrimas neblogai koreliuoja su nemielinizuotų simpatinių skaidulų funkcija [42, 43].
Ragenos konfokalinė mikroskopija - tai greitas ir neinvazyvus, kiekybinis tyrimo metodas, leidžiantis nustatyti smulkiụjų nervinių skaidulų pažaidą. Ragena yra inervuota $\mathrm{A} \delta$ ir $\mathrm{C}$ skaidulomis. Tai yra tankiausiai inervuota dalis žmogaus kūne. Vertinamas skaidulų tankis, šakotumas, ilgis, vingiuotumas [44]. Skirtingi centrai ir laboratorijos dažniausiai gauna ir naudoja skirtingus parametrus [45]. Šiam tyrimui naudoti klinikineje praktikoje dar trūksta duomenų apie specifiškumą ir jautrumą, esant skirtingoms neuropatinèms būklèms. Kontaktiniai šilumos sukelti potencialai, mikroneurografija yra naudojami moksliniais tikslais, bet ne klinikineje praktikoje [4].

\section{DIAGNOSTINIAI KRITERIJAI}

Klinikinių ekspertų grupè iš Europos diabeto asociacijos prièmė nuo ilgio priklausančios SSN diagnostikos kriterijus sergantiems cukriniu diabetu (CD), atkreipdama dèmesị ị klinikinius ligos požymius ir specialiuosius tyrimus [46], (2 pav.). Lauria ir kt. rekomenduoja taikyti šiuos kriterijus, itariant bet kokios priežasties SSN, nepriklausomai nuo to, ar neuropatija yra priklausanti nuo ilgio, ar ne [36]. Šiuo metu daugiausia įrodymų, diagnozuojant SSN, turi klinikinių simptomų ir sumažejjusių intraepiderminių nervinių skaidulų tankio derinys [8].

\section{PRIEŽASTYS}

Diagnozavus smulkiųų skaidulų neuropatiją ar ịtariant ją, būtina ieškoti galimų ligos priežasčių, kurios gali būti potencialiai gydomos. Nustatyta daugelis priežasčių, galinčių sukelti SSN (2 lentelè), tačiau apie 30-50 \% visų atvejų etiologija išlieka neaiški [34].

Iš žinomų SSN priežasčių metabolinès yra dažniausios ir ypač svarbios. Manoma, kad didžiausią jų dalị sudaro cukrinis diabetas, hipotiroidizmas ir uremija [47]. CD lemia net apie trečdalį visų SSN atvejų, dažnai kartu esant ir stambiưų skaidulų pažeidimo požymiams [46]. Esant tik sutrikusiai glikemijai nevalgius ar gliukozès tolerancijos sutrikimui, SSN gali vystytis nepastebimai, dar prieš atsirandant metaboliniam sindromui, todèl gliukozès tolerancijos mėginys turi būti rutiniškai atliekamas visiems pacientams, itariant SSN [48].

Kitos priežastys - infekcinès ligos, iš kurių daugiausia duomenų žinoma apie ŽIV ir priešvirusinio gydymo įtaką ligos išsivystymui, labai retais atvejais SSN gali sukelti kitos infekcinès ligos (pvz., hepatitas C) ar vakcinacija [49]. Neurotoksiniai veiksniai, alkoholis, chemoterapiniai preparatai taip pat gali paskatinti SSN, dažniausiai apimant kartu ir stambiąsias skaidulas [34, 50]. SSN taip pat gali kilti esant sisteminiam autoimuniniam ar uždegiminiam susirgimui, kaip Sjogreno sindromas ar sarkoidozè, ir esant retoms genetinėms ligoms: Fabry, Pompe ligai ir kt. $[8,51]$. 
2 lentelè. Smulkiụjų skaidulų neuropatijos priežastys. Adaptuota pagal Themistocleous AC [8]

\begin{tabular}{|c|c|}
\hline Pirminès & Antrinès \\
\hline Idiopatinès & Metabolinès \\
\hline $\begin{array}{l}\text { - Idiopatinė smulkiujų } \\
\text { skaidulų neuropatija }\end{array}$ & $\begin{array}{l}\text { - Gliukozės tolerancijos sutrikimas } \\
\text { - Cukrinis diabetas } \\
\text { - Hipotiroidizmas } \\
\text { - Dislipidemija } \\
\text { - Uremija } \\
\text { - Vitamino B } 12 \text { stoka }\end{array}$ \\
\hline Genetinès & Infekcinès \\
\hline \multirow{5}{*}{$\begin{array}{l}\text { - Natrio jonų } \\
\text { kanalopatijos } \\
(S C N 9 A, S C N 10 A, \\
S C N 11 A) \\
\text { • Šeiminė amiloidinė } \\
\text { polineuropatija } \\
\text { - Fabry, Pompe liga }\end{array}$} & $\begin{array}{l}\cdot \text { ŽIV } \\
\cdot \text { Hepatitas C }\end{array}$ \\
\hline & Toksinų ir vaistu sukeltos \\
\hline & $\begin{array}{l}\text { - Alkoholis } \\
\text { - Chemoterapiniai - bortezomibas } \\
\text { - Flekainidas }\end{array}$ \\
\hline & Imunologinès \\
\hline & $\begin{array}{l}\text { - Sarkoidozė } \\
\cdot \text { Sjogreno sindromas } \\
\text { - Reumatoidinis artritas } \\
\text { - Vaskulitas } \\
\text { - Paraneoplastinis sindromas }\end{array}$ \\
\hline
\end{tabular}

Atradus genų mutacijas, kurios lemia natrio jonų kanalų pažaidą, padidejjo galimas SSN priežasčių spektras [51]. Nustatyta, kad mutavęs $\mathrm{Na}_{\mathrm{v}} 1.7$ (SCN9A) jonų kanalas buvo rastas $28 \%$ sergančiųjų idiopatine SSN [52]. Identifikavus šias geno mutacijas $S C N 9 A, S C N 10 A$ (genas, koduojantis $\mathrm{Na}_{\mathrm{v}} 1.8$ subvienetą), $S C N 11 A$ (genas, koduojantis $\mathrm{Na}_{\mathrm{v}} 1.9$ subvienetą), nustatyta, kad jos nulemia ịtampos ir membranos kanalų laidumo pokyčius nociceptoriuose ir nugariniuose mazguose, taip pat simpatiniuose autonominiuose neuronuose, kurie galimai sukelia autonominės nervų sistemos disfunkciją [53]. Pakitęs natrio ir kalcio jonų kanalo jaudrumas didina viduląstelinio kalcio kiekį, kuris nulemia natrio jonų kanalo degeneraciją smulkiosiose nervinèse skaidulose. Vis dèlto tikslus tokios degeneracijos molekulinis mechanizmas ir izoliuotas smulkiujų skaidulų pažeidimas nėra iki galo aiškūs [54].

İtarus SSN, visiems pacientams turètų būti atliekama patikra dẻl galimų priežasčių identifikavimo.

\section{GYDYMAS}

Išsiaiškinus SSN priežastis, turètų būti taikomi, jei įmanoma, etiologiniai gydymo metodai, o esant idiopatinei SSN - skiriamas simptominis skausmo gydymas [34]. Pavyzdžiui, esant cukriniam diabetui, kuris galimai sukèlè SSN, pagrindinis gydymo metodas yra griežta glikemijos kontrolè, kuri stabdo ligos progresavimą ir palengvina klinikinius simptomus $[8,55]$. Esant diabetinei neuropatijai, kuri galimai susijusi su arterine hipertenzija, rūkymu, nu- tukimu, dislipidemija, svarbi šių rizikos veiksnių korekcija, taip pat turinti įtakos neuropatijos eigai [34]. Didelis mokslininkų dėmesys nukreiptas ị klinikinio efekto pasiekimą, bandant paveikti diabetinès neuropatijos patogenetinius mechanizmus, t. y. slopinant neuropatiją sukeliančius ir (ar) aktyvuojant neuropatiją slopinančius signalų kelius [56].

Nustačius Fabry ligą ir su ja susijusią SSN, tikslinga skirti alfa-galaktozidazę A, kuri ne tik sumažina neuropatinio pobūdžio skausmą, bet ir pagerina skausmo bei temperatūros jutimo slenkstį rankose ir kojose [57]. Lietuvoje yra registruoti du pakaitinès alfa-galaktozidazès A preparatai: „Replagal“" ir „Fabrazyme“.

Pastebèta, kad imuninès sistemos sukeltoms būklëms gydyti skirtas imunomoduliuojantis gydymas lengvina ir SSN sukeltus simptomus, tačiau tikslesnèms rekomendacijoms reikalingi papildomi, didesnès imties, kontroliuojami tyrimai, galintys patvirtinti šiuos rezultatus [33].

Šiuo metu pasaulyje nèra prieinamo SSN neuroprotekcinio gydymo. Atlikta nemažai tyrimų, analizuojančių nervo augimo faktoriaus poveiki, siekiant regeneruoti nervines skaidulas, ypač sergantiems diabetine neuropatija [8], tačiau šiuose tyrimuose trūksta efektyvumo įrodymų. Visgi manoma, kad pirmenybė turètų būti teikiama etiologiniam gydymui, taip išvengiant tokių komplikacijų, kaip SSN, išsivystymo.

Pagrindinė SSN komplikacija yra neuropatinio pobūdžio skausmas, turintis simptominị gydymą, tačiau klinikinėje praktikoje pastebėta, kad gydymas ne visada yra efektyvus [8]. Išskiriami šie vaistai, geriausiai kontroliuojantys neuropatinio pobūdžio skausmą: gabapentinas arba pregabalinas ir antidepresantai [6]. Tricikliai antidepresantai (amitriptilinas, nortriptilinas) veiksmingai malšina neuropatinị skausmą, tačiau pasižymi dažnesnèmis nepageidaujamomis reakcijomis, todèl selektyvūs serotonino ir noradrenalino reabsorbcijos inhibitoriai (duloksetinas, venlafaksinas) yra tinkama alternatyva, siekiant išvengti šalutinio poveikio, nors analgetinis poveikis yra netoks stiprus kaip triciklių antidepresantų [58]. Šie preparatai turi būti dozuojami atsižvelgiant ị klinikinị efektyvumą, toleravimą ir nepageidaujamas reakcijas. Jei pirmos eilès gydymas yra neefektyvus ir skausmas išlieka intensyvus, tikslinga skirti daugiadalyki gydymą skausmo klinikoje [8]. $2019 \mathrm{~m}$. Olandijoje atliktas tyrimas, kurio metu buvo vertintas lakozamido efektyvumas pacientams, sergantiems izoliuota SSN ir turintiems nustatytą $S C N 9 A$ geno mutaciją. Jo metu nustatytas efektyvumas, gydant neuropatinio pobūdžio skausmą, taip pat gautas teigiamas efektas gerinant miego kokybę, tačiau vaistui taikyti klinikinejje praktikoje dar trūksta didesnès imties ir ilgesnès trukmès tyrimų [59].

\section{APIBENDRINIMAS}

SSN turi būti įtariama visiems pacientams, besiskundžiantiems lètiniu neuropatinio pobūdžio skausmu, temperatū- 
ros jutimo ir (ar) autonominės nervų sistemos sutrikimais galūnėse. Diagnozuojant šią ligą, svarbi ligos anamnezè, klinikinis neurologinis ištyrimas, auksiniu standartu pripažinta odos biopsija, vertinant intraepiderminių skaidulų tanki, autonominès funkcijos ir funkciniai jutimų testai. Standartinè ENMG dažniausiai būna neinformatyvi, jei netaikoma OTP, skausminio fleksinio reflekso (RIII atsako) tyrimas ar lazerio sukelti potencialai, kurie yra vertinga papildoma priemonè.

Kadangi ankstyva šios ligos diagnostika ir tikslus ligos etiologijos identifikavimas klinikinejje praktikoje vis dar išlieka iššūkiu, optimistiškai tikimasi, kad augantis susidomejjimas naujais, galimai su SSN susijusiais mechanizmais, tokiais kaip natrio jonų kanalų mutacijos, pagerins ligos diagnostiką ir sudarys galimybę plačiau taikyti etiopatogenezinius gydymo metodus.

\section{Literatūra}

1. Cazzato D, Lauria G. Small fibre neuropathy. Curr Opin Neurol 2017; 30(5): 490-9. https://doi.org/10.1097/ WCO.0000000000000472

2. Hoitsma E, Reulen JPH, de Baets M, Drent M, Spaans F, Faber CG. Small fiber neuropathy: a common and important clinical disorder. J Neurol Sci 2004; 227(1): 119-30. https://doi.org/10.1016/j.jns.2004.08.012

3. Peters MJ, Bakkers M, Merkies IS, et al. Incidence and prevalence of small-fiber neuropathy: a survey in the Netherlands. Neurology 2013; 81: 1356-60. https://doi.org/10.1212/ WNL.0b013e3182a8236e

4. Terkelsen AJ, Karlsson P, Lauria G, Freeman R, Finnerup NB, Jensen TS. The diagnostic challenge of small fibre neuropathy: clinical presentations, evaluations, and causes. Lancet Neurol 2017; 16(11): 934-44. https://doi.org/ 10.1016/S1474-4422(17)30329-0

5. Devigili G, Tugnoli V, Penza P, Camozzi F, Lombardi R, Melli G, et al. The diagnostic criteria for small fibre neuropathy: from symptoms to neuropathology. Brain 2008; 131(Pt 7): 1912-25. https://doi.org/10.1093/brain/awn093

6. Sène D. Small fiber neuropathy: diagnosis, causes, and treatment. Joint Bone Spine 2018; 85(5): 553-9. https://doi.org/ 10.1016/j.jbspin.2017.11.002

7. Garšvienė D, Vaičienè-Magistris N, Petrikonis K. Gliukozės toleravimo sutrikimo sąlygotos polineuropatijos klinikinių simptomu spektras. Neurologijos seminarai 2012; 16(51): 53-60.

8. Themistocleous AC, Ramirez JD, Serra J, Bennett DLH. The clinical approach to small fibre neuropathy and painful channelopathy. Pract Neurol 2014; 14(6): 368-79. https://doi.org/10.1136/practneurol-2013-000758

9. Gibbons CH. Small fiber neuropathies. Continuum 2014; 20(5 Peripheral Nervous System Disorders): 1398-412. https://doi.org/10.1212/01.CON.0000455874.68556.02

10. Jensen TS, Finnerup NB. Allodynia and hyperalgesia in neuropathic pain: clinical manifestations and mechanisms. Lancet Neurol 2014; 13(9): 924-35. https://doi.org/10.1016/ S1474-4422(14)70102-4

11. Khoshnoodi MA, Truelove S, Burakgazi A, Hoke A, Mammen AL, Polydefkis M. Longitudinal assessment of small fiber neuropathy: evidence of a non-length-dependent distal axonopathy. JAMA Neurol 2016; 73(6): 684-90. https://doi.org/10.1001/jamaneurol.2016.0057
12. Waheed W, Boyd J, Khan F, Mount SL, Borden NM, Tandan R. Double trouble: para-neoplastic anti-PCA-2 and CRMP-5-mediated small fibre neuropathy followed by chorea associated with small cell lung cancer and evolving radiological features. BMJ Case Rep 2016; 2016: bcr2016215158. https://doi.org/10.1136/bcr-2016-215158

13. Goebel A, Lecky B, Smith L-J, Lunn MP. Pain intensity and distribution in chronic inflammatory demyelinating polyneuropathy. Muscle Nerve 2012; 46(2): 294-5. https://doi.org/10.1002/mus.23355

14. Üçeyler N, Zeller D, Kahn A-K, Kewenig S, Kittel-Schneider S, Schmid A, et al. Small fibre pathology in patients with fibromyalgia syndrome. Brain 2013; 136(Pt 6): 1857-67. https://doi.org/10.1093/brain/awt053

15. Cazzato D, Castori M, Lombardi R, Caravello F, Bella ED, Petrucci A, et al. Small fiber neuropathy is a common feature of Ehlers-Danlos syndromes. Neurology 2016; 87(2): 155-9. https://doi.org/10.1212/WNL.0000000000002847

16. Thaisetthawatkul P, Fernandes Filho JA, Herrmann DN. Autonomic evaluation is independent of somatic evaluation for small fiber neuropathy. J Neurol Sci 2014; 344(1-2): 51-4. https://doi.org/10.1016/j.jns.2014.06.017

17. Angel RW, Hofmann WW, Eppler W. Silent period in patients with parkinsonian rigidity. Neurology 1966; 16: 529-32. https://doi.org/10.1212/WNL.16.5.529

18. Svilpauskaite J, Truffert A, Vaiciene N, Magistris MR. Electrophysiology of small peripheral nerve fibers in man. A study using the cutaneous silent period. Medicina 2006; 42(4): 300-13.

19. Uncini A, Kujirai T, Gluck B, et al. Silent period induced by cutaneous stimulation. Electroencephalogr Clin Neurophysiol 1991; 81: 344-52. https://doi.org/10.1016/ 0168-5597(91)90023-Q

20. Corsi FM, Fausti S, Serrao M, et al. Electromyographic mixed nerve and cutaneous silent period in evaluating the A-delta fibres in a patient with hereditary sensory-autonomic neuropathy. Funct Neurol 2002; 17: 31-4.

21. Floeter MK. Cutaneous silent periods. Muscle Nerve 2003; 28(4): 391-401. https://doi.org/10.1002/mus. 10447

22. Onal MR, Ulas UH, Oz O, Bek VS, Yucel M, Taslipinar A, et al. Cutaneous silent period changes in Type 2 diabetes mellitus patients with small fiber neuropathy. Clin Neurophysiol 2010; 121(5): 714-8. https://doi.org/10.1016/ j.clinph.2009.12.024

23. Garšvienè D, Švilpauskė J, Vaičienè-Magistris N. The study of nerve conduction and cutaneous silent period in impaired glucose tolerance neuropathy. Baltic Endocrinology 2012; 6(1,2): 1-7.

24. Hugon M. Exteroceptive reflexes to stimulation of the sural nerve in normal man. In: Desmedt JE, ed. Human reflexes, pathophysiology of motor systems, methodology of human reflexes. Basel: Karger, 1973; 713-29. https://doi.org/ 10.1159/000394186

25. Micalos PS, Drinkwater EJ, Cannon J, Arendt-Nielsen L, Marino FE. Reliability of the nociceptive flexor reflex (RIII) threshold and association with pain threshold. Eur J Appl Physiol 2009; 105(1): 55-62. https://doi.org/10.1007/ s00421-008-0872-x

26. Sandrini G, Alfonsi E, Bono G, Facchinetti F, Montalbetti L, Nappi G. Circadian variations of human flexion reflex. Pain 1986; 25(3): 403-10. https://doi.org/10.1016/ 0304-3959(86)90245-9 
27. Pradalier A, Dry J, Willer JC, Boureau F. Obesity and the nociceptive reflex (author's transl.). Pathol Biol (Paris) 1980; 28(7): 462-4.

28. Edwards L, McIntyre D, Carroll D, Ring C, Martin U. The human nociceptive flexion reflex threshold is higher during systole than diastole. Psychophysiology 2002; 39(5): 678-81. https://doi.org/10.1111/1469-8986.3950678

29. Chong PST, Cros DP. Technology literature review: quantitative sensory testing. Muscle Nerve 2004; 29(5): 734-47. https://doi.org/10.1002/mus.20053

30. Maier C, Baron R, Tölle TR, Binder A, Birbaumer N, Birklein F, et al. Quantitative sensory testing in the German Research Network on Neuropathic Pain (DFNS): somatosensory abnormalities in 1236 patients with different neuropathic pain syndromes. Pain 2010; 150(3): 439-50. https://doi.org/10.1016/j.pain.2010.05.002

31. Rolke R, Baron R, Maier C, Tölle TR, Treede R-D, Beyer A, et al. Quantitative sensory testing in the German Research Network on Neuropathic Pain (DFNS): standardized protocol and reference values. Pain 2006; 123(3): 231-43. https://doi.org/10.1016/j.pain.2006.01.041

32. McCarthy BG, Hsieh ST, Stocks A, Hauer P, Macko C, Cornblath DR, et al. Cutaneous innervation in sensory neuropathies: evaluation by skin biopsy. Neurology 1995 45(10): 1848-55. https://doi.org/10.1212/WNL.45.10.1848

33. Üçeyler N, Geng A, Reiners K, Toyka KV, Sommer C. Nonsystemic vasculitic neuropathy: single-center follow-up of 60 patients. J Neurol 2015; 262(9): 2092-100. https://doi.org/10.1007/s00415-015-7813-5

34. Hoeijmakers JG, Faber CG, Lauria G, Merkies IS, Waxman SG. Small-fibre neuropathies - advances in diagnosis, pathophysiology and management. Nat Rev Neurol 2012; 8(7): 369-79. https://doi.org/10.1038/nrneurol. 2012.97

35. Lauria G, Hsieh ST, Johansson O, Kennedy WR, Leger JM, Mellgren SI, et al. European Federation of Neurological Societies/Peripheral Nerve Society Guideline on the use of skin biopsy in the diagnosis of small fiber neuropathy. Report of a joint task force of the European Federation of Neurological Societies and the Peripheral Nerve Society. Eur J Neurol 2010; 17(7): 903-12, e44-9.

36. Lauria G. Small fibre neuropathies. Curr Opin Neurol 2005; 18(5): 591-7. https://doi.org/10.1097/01.wco.0000177330. 35147.70

37. Thompson RJ, Doran JF, Jackson P, Dhillon AP, Rode J. PGP 9.5 - a new marker for vertebrate neurons and neuroendocrine cells. Brain Res 1983; 278(1-2): 224-8. https://doi.org/10.1016/0006-8993(83)90241-X

38. Wang L, Hilliges M, Jernberg T, Wiegleb-Edström D, Johansson O. Protein gene product 9.5-immunoreactive nerve fibres and cells in human skin. Cell Tissue Res 1990; 261(1): 25-33. https://doi.org/10.1007/BF00329435

39. Cheng HT, Dauch JR, Porzio MT, Yanik BM, Hsieh W, Smith AG, et al. Increased axonal regeneration and swellings in intraepidermal nerve fibers characterize painful phenotypes of diabetic neuropathy. J Pain 2013; 14(9): 941-7. https://doi.org/10.1016/j.jpain.2013.03.005

40. Thaisetthawatkul P, Fernandes Filho JAM, Herrmann DN. Contribution of QSART to the diagnosis of small fiber neuropathy. Muscle Nerve 2013; 48(6): 883-8. https://doi.org/ 10.1002/mus.23891

41. Blackmore D, Siddiqi ZA. Diagnostic criteria for small fiber neuropathy. J Clin Neuromuscul Dis 2017; 18(3): 125-31. https://doi.org/10.1097/CND.0000000000000154
42. Uncini A, Pullman SL, Lovelace RE, Gambi D. The sympathetic skin response: normal values, elucidation of afferent components and application limits. J Neurol Sci 1988; 87: 299-306. https://doi.org/10.1016/0022-510X(88)90254-7

43. Shahani BT, Halperin JJ, Boulu P, Cohen J. Sympathetic skin response - a method of assessing unmyelinated axon dysfunction in peripheral neuropathies. J Neurol Neurosurg Psychiatry 1984; 47(5): 536-42. https://doi.org/10.1136/ jnnp.47.5.536

44. Oliveira-Soto L, Efron N. Morphology of corneal nerves using confocal microscopy. Cornea 2001; 20(4): 374-84. https://doi.org/10.1097/00003226-200105000-00008

45. Petropoulos IN, Alam U, Fadavi H, Asghar O, Green P, Ponirakis G, et al. Corneal nerve loss detected with corneal confocal microscopy is symmetrical and related to the severity of diabetic polyneuropathy. Diabetes Care 2013; 36(11): 3646-51. https://doi.org/10.2337/dc13-0193

46. Tesfaye S, Boulton AJM, Dyck PJ, Freeman R, Horowitz M, Kempler P, et al. Diabetic neuropathies: update on definitions, diagnostic criteria, estimation of severity, and treatments. Diabetes Care 2010; 33(10): 2285-93. https://doi.org/10.2337/dc10-1303

47. Khan S, Zhou L. Characterization of non-length-dependent small-fiber sensory neuropathy. Muscle Nerve 2012; 45(1): 86-91. https://doi.org/10.1002/mus.22255

48. Bansal N. Prediabetes diagnosis and treatment: a review. World J Diabetes 2015; 6(2): 296-303. https://doi.org/ 10.4239/wjd.v6.i2.296

49. Cherry CL, Skolasky RL, Lal L, Creighton J, Hauer P, Raman SP, et al. Antiretroviral use and other risks for $\mathrm{HIV}$-associated neuropathies in an international cohort. Neurology 2006; 66(6): 867-73. https://doi.org/10.1212/ 01.wnl.0000203336.12114.09

50. Mellion M, Gilchrist JM, De La Monte S. Alcohol-related peripheral neuropathy: nutritional, toxic, or both? Muscle Nerve 2011; 43(3): 309-16. https://doi.org/10.1002/ mus. 21946

51. Bennett DLH, Woods CG. Painful and painless channelopathies. Lancet Neurol 2014; 13(6): 587-99. https://doi.org/10.1016/S1474-4422(14)70024-9

52. Faber CG, Hoeijmakers JGJ, Ahn H-S, Cheng X, Han C, Choi J-S, et al. Gain of function Na1.7 mutations in idiopathic small fiber neuropathy. Ann Neurol 2012; 71(1): 26-39. https://doi.org/10.1002/ana.22485

53. Han C, Hoeijmakers JGJ, Liu S, Gerrits MM, te Morsche RHM, Lauria G, et al. Functional profiles of SCN9A variants in dorsal root ganglion neurons and superior cervical ganglion neurons correlate with autonomic symptoms in small fibre neuropathy. Brain 2012; 135(Pt 9): 2613-28. https://doi.org/10.1093/brain/aws187

54. Rolyan H, Liu S, Hoeijmakers JG, Faber CG, Merkies IS, Lauria G, et al. A painful neuropathy-associated Nav1.7 mutant leads to time-dependent degeneration of small-diameter axons associated with intracellular $\mathrm{Ca} 2+$ dysregulation and decrease in ATP levels. Mol Pain 2016; 12. https://doi.org/ $10.1177 / 1744806916674472$

55. Mehra S, Tavakoli M, Kallinikos PA, Efron N, Boulton AJM, Augustine T, et al. Corneal confocal microscopy detects early nerve regeneration after pancreas transplantation in patients with type 1 diabetes. Diabetes Care 2007; 30(10): 2608-12. https://doi.org/10.2337/dc07-0870

56. Dewanjee S, Das S, Das AK, Bhattacharjee N, Dihingia A, Dua TK, et al. Molecular mechanism of diabetic neuropathy 
and its pharmacotherapeutic targets. Eur J Pharmacol 2018; 833: 472-523. https://doi.org/10.1016/j.ejphar.2018.06.034

57. Schiffmann R, Floeter MK, Dambrosia JM, Gupta S, Moore DF, Sharabi Y, et al. Enzyme replacement therapy improves peripheral nerve and sweat function in Fabry disease. Muscle Nerve 2003; 28(6): 703-10. https://doi.org/10.1002/ mus. 10497

58. Finnerup NB, Attal N, Haroutounian S, McNicol E, Baron R, Dworkin RH, et al. Pharmacotherapy for neuropathic pain in adults: a systematic review and meta-analysis. Lancet Neurol 2015; 14(2): 162-73. https://doi.org/10.1016/S14744422(14)70251-0

59. de Greef BTA, Hoeijmakers JGJ, Geerts M, Oakes M, Church TJE, Waxman SG, et al. Lacosamide in patients with Nav1.7 mutations-related small fibre neuropathy: a randomized controlled trial. Brain 2019; 142(2): 263-75. https://doi.org/10.1093/brain/awy329

\section{E. Paulèkas, D. Garšvienė, K. Petrikonis}

\section{SMALL FIBER NEUROPATHY: CLINICAL PRESENTATION, DIAGNOSTIC METHODS, POSSIBLY CAUSES AND TREATMENT}

\section{Summary}

Small fiber neuropathy (SFN) is a disorder affecting the thin myelinated $\mathrm{A} \delta$ and unmyelinated $\mathrm{C}$ nerve fibers, which usually presents clinically with symmetrical, length-dependent neuropathic and autonomic symptoms. In some cases, a nonlength-dependent clinical presentation may develop instead, characterized by focal or multifocal symptoms. Diagnosis of pure SFN remains difficult in situations when no pathological findings are detected during nerve conduction tests (using standard electroneuromyography) and patients present with unusual subjective symptoms. However, quantitative measurement of intraepidermal nerve fiber density (INFD) in skin biopsy and quantitative evaluation of sensory or autonomic symptoms may facilitate the diagnostic process. There is a plethora of possible SFN causes, such as metabolic, immune system mediated or neurotoxic factors, although in about $50 \%$ of cases, the precise etiology remains unknown. In recent years, mutations in genes SCN9A and SCN10A that encode voltage-gated sodium channels $\mathrm{Na}_{\mathrm{v}} 1.7$ and $\mathrm{Na}_{\mathrm{v}} 1.8$, respectively, have been linked to nearly a third of SFN cases that previously were thought of as idiopathic. In clinical practice, it is important to identify possible SFN causes and prescribe medications that not only treat the symptoms but directly intervene in the etiopathogenetic mechanisms of the disorder itself. In this review, we examine clinical signs, possible causes, available diagnostic methods and treatment of SFN.

Keywords: small fiber neuropathy, painful neuropathy, skin biopsy, intraepidermal nerve fibers, quantitative sensory testing, quantitative sudomotor axon reflex test, confocal corneal microscopy.

Gauta:

Priimta spaudai: 20200127
20200211 